Adamska A., Dąbrowski T., Reputation and regulations as market and non-market mechanisms to reduce bifurcated risk, „Ekonomia i Prawo. Economics and Law”, Polszakiewicz B., Boehlke J. (ed.), Vol. 14, No. 2/2015, pp. 155-168. DOI: http://dx.doi.org/10.12775/EiP.2015.009.

\author{
Agata Adamska*, Tomasz J. DąbroWski*
}

\title{
REPUTATION AND REGULATIONS AS MARKET AND NON-MARKET MECHANISMS TO REDUCE BIFURCATED RISK
}

\author{
SUMMARY
}

This paper presents a new concept of bifurcated risk and market and non-market mechanisms reducing the risk. Bifurcated risk occurs in different situations, and it is characterized by a disruption of the relationship between decision-making and the resulting consequences. The bifurcated risk is followed by a number of very negative consequences in the form of disturbances of institutional order and a decrease in the level of generalized trust which leads to an increase in transaction costs. Therefore, it is important to reduce this risk, by means of using various market and nonmarket mechanisms. This article presents two such mechanisms - reputation and regulations. Reputation reduces the bifurcated risk, because on one hand, it creates stimuli which discourage decision-makers from taking this risk, on the other hand helps to reduce information asymmetry, allowing entities susceptible to the effects of risks to avoid entering into relationships with entities which are the source of this risk. Regulations in turn play a greater role not in preventing the emergence

"Agata Adamska, Warsaw School of Economics, Collegium of Business Administration, Institute of Corporate Finance and Investment, Corporate Finance Management Unit, al. Niepodległości 162, 02-554 Warszawa, Poland, phone: +48 225649 329, e-mail: agata. adamska@sgh.waw.pl (corresponding author).

** Tomasz J. Dąbrowski, Warsaw School of Economics, Collegium of Business Administration, Institute of Value Management, Value-Based Marketing Unit, al. Niepodległości 162, 02-554 Warszawa, Poland, phone: +48 225648 655, e-mail: tomasz.dabrowski@sgh.waw.pl. 
of the bifurcated risk, but in mitigating the negative consequences associated with the risk. Reputation and regulations are complementary and as mechanisms to reduce the bifurcated risk can occur together.

Keywords: uncertainty, opportunistic behaviour, trust, agency problem, institutional order

JEL Classification: D02, K20

\section{INTRODUCTION}

Risk has been a part of human life from the very beginning. Despite of that it has not been properly examined, inter alia, because it is difficult to define the very concept due to its multifaceted and ambiguous nature ${ }^{1}$. Sources of risk should be sought in the changeability of nature, as well as in a subjective lack of information. Uncertainty and risk are inherent characteristics of reality arising not only from the number, complexity, and instability of their components, but also from interactions between these components and also because human cognitive abilities are limited.

From the economic point of view - as it was recognized by classical economics - risk is one of the elements of normal environment of entrepreneurs, who receive remuneration for taking risk $^{2}$. Sometimes, however, there are situations where the relationship between risk and remuneration is disturbed in the sense that the benefits of taking risks are privatized, and the negative effects transferred to other entities. The bifurcation of risk takes place, consisting in separating decisions taken by entities aware of the risk from the consequences (usually negative) resulting therefrom, which are imposed on other entities (in the case of a party exposed to loss it is not really a risk in the strict sense, but rather uncertainty). This situation is very harmful, from the economic and social point of view, and in addition, it distorts the institutional order ${ }^{3}$. Therefore, it is important to identify mechanisms which can effectively reduce the bifurcated risk and its effects. The article presents two

${ }^{1}$ A. Adamska, Ryzyko w dziatalności przedsiębiorstwa - podstawowe zagadnienia, [in:] A. Fierla (ed.), Ryzyko w dziatalności przedsiębiorstw. Wybrane aspekty, Szkoła Główna Handlowa, Warszawa 2009.

2 A. Adamska, Ryzyko jako przedmiot nauk ekonomicznych, [in:] K. Kuciński (ed.), Ryzyko lokalizacji przedsiębiorstw, CeDeWu, Warszawa 2014.

3 A. Adamska, Ryzyko rozszczepione jako przejaw naruszonej równowagi tadu instytucjonalnego w gospodarce, [in:] S. Rudolf (ed.), Teoretyczny i praktyczny wymiar nowej ekonomii instytucjonalnej, Kielce (in print). 
types of such mechanisms - one is of market nature and the other of nonmarket nature.

\section{THE BIFURCATED RISK - AN OUTLINE OF THE CONCEPT}

Risk is an inherent part of economic processes. Usually an entity which takes risk bears its consequences - if the result is positive, an entity benefits (in financial terms it is defined as profit), and if the consequences are negative - fails (in financial terms it is a loss). However, there are situations in which this causal relationship becomes disrupted, one entity takes the risk and another, in whole or in part, bears the consequences. This means the appearance of a specific form of risk, which can be called the bifurcated risk. This type of risk can be observed in many areas of business operation and in the relations between firms and various groups of stakeholders: shareholders, customers or communities.

The bifurcated risk occurs when based on the contract, one party (the principal) transfers the right to make certain decisions, e.g., to manage a capital company, to another party (the agent). The resulting agency relationship is not precisely specified, because due to the long duration of the agreement between the two parties and the uncertainty of the environment, as well as the difficulty to monitor the parties' activities and expenditures incurred by them, it is impossible to formulate an explicit contract between shareholders and the management, a contract which would specify a full range of duties of management and cover all possible situations. The relationship of representation is therefore defined by the terms of the incomplete, default, and implicit contract ${ }^{4}$, in which an open question remains as to the decision-making in situations not covered by the contract. This leads to a relatively high degree of autonomy of agent's decision-making, while the ultimate consequences of decisions taken by the agent (both positive and negative) are born by the principal. The decisions taken by the management board result in the creation of a portfolio comprising different types of risks to which the firm is exposed (particular types of risks either reinforce each other or cancel each other out, depending on the correlation between them). At the same time the shareholder as the owner of part of shares becomes the co-owner of the risk portfolio. One should note, however, that in some cases there may be a divergence

${ }^{4}$ C. Mesjasz, Kontrakty niekompletne jako podstawa teoretyczna nadzoru korporacyjnego, [in:] S. Rudolf (ed.), Strategiczne obszary nadzoru korporacyjnego zewnętrznego i wewnętrznego, Wydawnictwo Uniwersytetu Łódzkiego, Łódź 2002, p. 58. 
between the objectives of shareholders and management. In a situation where "principals (e.g., shareholders) do not have full control over proxies acting on their behalf (e.g., managers), the proxies can sometimes engage in transactions taking into account interests other than the best interests of their

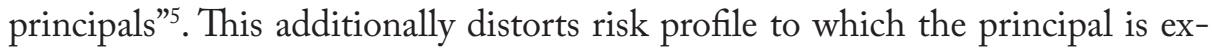
posed. In this case, the bifurcation of risk means that the decisions, which result in the development of a specific portfolio with various types of risk, are taken in the firm, and their financial implications (both profits and losses) are transferred to shareholders.

Apart from cases where total financial consequences are transferred to entities other than the decision makers, the bifurcated risk may also asymmetrically burden different groups of stakeholders with the effects of the risk. The relationship between firms and customers is an example of such situation. This relationship is characterized by a high level of information asymmetry e.g., in regard to products and services. The increasing complexity and diversity of goods and services on the market often make it impossible for potential consumers to understand the full implications of purchasing products or services and using them. This problem will be even more evident in the future, because in conditions of dynamic technological progress the owner of the product will not only not know and understand how it works, but often will not be able control it. For an example, devices which on-line automatically install and update software without the user's knowledge, but also various types of machines and vehicles performing real tasks in physical space, which act autonomously and no one controls them at a given moment. In both instances damages may occur not only to users, but also to third parties. For example, a self-driving car, designed so that it can cover the programmed route alone. If it gets into an accident the question arises: who is responsible for the damages? The manufacturer, the owner of the vehicle, the passenger, the road traffic service, the navigation system service, or some other entity?

Information asymmetry in the area of products and services raises the socalled moral hazard issues, because possible negative consequences of risky activities to a large extent will not be borne by the operator, but by the buyers. Assessing the situation from the point of view of users one should speak about the uncertainty of whether the product will be safe and will meet users' needs, rather than risk in the strict sense - it is not possible to model the probability and the corresponding results in this case. This means that

\footnotetext{
${ }^{5}$ A. Rappaport, Wartośc dla akcjonariuszy, WIG-Press, Warszawa 1999, p. 3.
} 
the analysis of the bifurcated should go beyond the very risk and take into account the category of uncertainty.

Buyers, as opposed to a firm, due to the lack of necessary data are not able to calculate the risk involved, and are left with uncertainty in choosing a product made by one or another manufacturer. In this case the bifurcated risk mechanism works in such a way that quantifiable risk, which is viewed by the decision-making representatives of the firm in terms of the results and probability, in the realm of positive effects is retained in the firm (and consequently, transferred to shareholders), while negative implications in large part, if not predominantly, are transferred to customers.

The effects of the bifurcated risk, transformed onto the uncertainty can also affect another group of stakeholders - taxpayers, as members of the given community. The issue of the bifurcated risk concerns also large "too big to fail" (TBTF) firms. Firms belonging to this category, although they are not directly equipped with state guarantees, "have such significant elements of impact on the state apparatus that the state is not able to apply classical free-market mechanisms to them — including a full bankruptcy. Departure from the principles of free competition creates the risk of irresponsible business policy, based on specific calculations that the state will invariably come

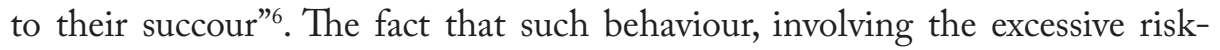
taking by management boards of these enterprises, is indeed taking place has been shown by the course of events that led to the recent financial crisis. This crisis was not the first event of this kind caused by moral hazard of managers of large financial institutions. One could get the impression that the scale of irresponsible risk-taking behaviour over the last several years has been steadily increasing. That was a game between management boards of these institutions and national governments. "Behaving in the same way during subsequent crises the public player has earned the reputation of never betraying the trust placed in him. This explains why the private player was willing to take greater risks, and explains the severity of moral hazard phenomena among entities administering private funds"7.

In the case of the TBTF enterprises, the bifurcated risk takes an even more dangerous form than that described in the context of the relationship between an economic entity and customers, because buyers can at least partial-

${ }^{6}$ P. Wiśniewski, Pokusa nadużycia implikowanej pomocy kredytowej. Jak ograniczyć spoteczne koszty funkcjonowania przedsiębiorstw ważnych dla interesów państwa?, „Studia i Prace Kolegium Zarządzania i Finansów”, Vol. 101/2010, pp. 224-235.

7 T. Dąbrowski, Kryzys a teoria gier, czyli na czym polega błąd, „Kwartalnik Nauk o Przedsiębiorstwie”, No. 1/2012, pp. 59-65. 
ly reduce uncertainty by following e.g., a brand or recommendations of consumer organizations. With regard to the TBTF firms it is not only impossible, but in addition the distribution of benefits and losses is more pronounced - the possible profits from taking risks go to the same enterprise, its management board, lower-level executives, and shareholders, while the potential losses are ultimately borne by other entities, often loosely or not at all related to the enterprise. In such a situation, taking risks, even if it is formally defined by the amount of potential loss or gain and by the probability of occurrence of loss or gain, in practical terms means that the decision maker gains a secure position. For those who sustain potential negative effects, however, this position is open and in no way manageable. Members of the public are not only unaware of this uncertainty, but they also have no effective tools to reduce this phenomenon.

These examples do not exhaust the whole spectrum of situations in which the bifurcated risk occurs. They were selected in order to show the diversity of cases in which decisions taken in the enterprise are at least partially separated from the effects (most often it relates to the negative consequences), affecting other entities on which the risk was transferred. So the question arises whether these entities can and should be protected against the consequences of such actions? And if so, how?

\section{REPUTATION AS A MARKET MECHANISM TO REDUCE THE BIFURCATED RISK}

Reputation, as well as the risk, are complex phenomena, multidimensional and hence, difficult to define. The economic literature describes reputation mainly in the context of economic entities, although the term can also refer to individuals (persons) or groups - e.g., the reputation of the President, or the reputation of the management board. Defining the reputation individual authors draw attention to its various features quite often referring directly or indirectly to signalling theory. Many definitions emphasize the relationship of reputation with previous actions taken by the entity. For example, K. Weigelt and C. Camerer determined the reputation as "a set of attributes ascribed to a firm, inferred from the firm's past actions" ${ }^{8}$. Likewise, D.K. Basdeo et al. observed that the actions taken by the entity "provide visible signals up-

${ }^{8}$ K. Weigelt, C. Camerer, Reputation and Corporate Strategy: a Review of Recent Theory and Applications, „Strategic Management Journal” Vol. 9, No. 5/1988, pp. 443-454. 
on which stakeholders infer various characteristics of the firm. In aggregate, these inferences determine the reputation of the firm"

E. Yoon et al. stressed the relationship of reputation with past actions of the firm even more distinctly "the reputation of the firm reflects the history of its past actions"10.

P. Herbig and J. Milewicz drew their attention to a slightly different feature of reputation defining reputation as "the estimation of the consistency over time of an attribute of an entity. This estimation is based upon the entity's willingness and ability to repeatedly perform an activity in a similar fashion. Reputation is an aggregate composite of all previous transactions over the life of the entity, a historical notion, and requires consistency of an entity's actions over a prolonged time" ${ }^{11}$. The definition assigns primary importance to the willingness and ability of the entity to maintain a coherent and consistent manner of conduct over time. Therefore, reputation is based on past actions, but only in so far as they are characterized by a pattern. Many definitions also highlight the evaluation and stratification nature of reputation. According to C.J. Fombrun and M. Shanley "reputations represent publics' cumulative judgements of firms over time"12 and in the opinion of A.M. Spence reputation is the outcome of a competitive process in which firms signal their key characteristics to constituents to maximize their social status $^{13}$. Evaluation requires establishing a reference point to formulate assessments. The most common assessments involve the expectations of stakeholders, therefore, S.L. Wartick characterized reputation as "the aggregation of a single stakeholder's perceptions of how well organizational responses are meeting the demands and expectations of many organizational stakeholders"14

9 D.K. Basdeo, K.G. Smith, C.M. Grimm, V.P. Rindova, P.J. Derfus, The Impact of Market Actions on firm Reputation, „Strategic Management Journal” Vol. 27, No. 2/2006, pp. 12051219.

${ }^{10}$ E. Yoon, H.G. Guffey, V. Kijewski, The effects of information and company reputation on intentions to buy a business service, "Journal of Business Research” Vol. 27, No. 3/1993, pp. 215228.

${ }^{11}$ P. Herbig, J. Milewicz, To be or not to be... credible that is: a model of reputation and credibility among competing firms, „Marketing Intelligence\&Planning” Vol. 13, No. 6/1995, pp. 24-33.

12 C.J. Fombrun, M. Shanley, What's in a name? Reputation building and corporate strategy, „Academy of Management Journal”, Vol. 33, No. 2/1990, pp. 233-258.

13 A.M. Spence, Market Signaling: Informational Transfer in Hiring and Related Screening Processes, Harvard University Press, Cambridge 1974.

14 S.L. Wartick, The relationship between intense media exposure and change in corporate reputation, „Business and Society”, Vol. 31, No. 1/1992, pp. 33-49. 
and S. Waddock described reputation as "the organization's perceived capacity to meet their stakeholders expectations" 15 .

These features of reputation accentuated in the above definitions effectively play the role of the market mechanism to reduce bifurcated risk. Reputation not only affects the development of a system of incentives to reduce the tendency to opportunistic behaviour which gives rise to such a risk, but it also creates conditions that make it difficult to transfer the negative effects of the risk on other entities. Having a reputation (especially good) is a desired state, due to the many benefits that are associated with it ${ }^{16}$. Therefore, entities, both individuals and organizations, are interested to build, maintain, strengthen and protect it. This in turn requires them to respond to the expectations of stakeholders to a greater extent than the competitors do in the fight for status. This alone reduces the motivation for opportunistic behaviour. It can therefore be concluded that the "reputation acts as an implicit contractual enforcement mechanism between stakeholders in the corporate domain whose various claims cannot be explitly enforced" ${ }^{17}$. In the case of agency relationship the agent who strives to build his good reputation will have to act in accordance with the interest of the principal, even if that interest is not in line with his interests. This is because in the long run a good reputation increases the market value of the agent, and thus he can waive his own short-term benefits in the interests of the principal as an investment.

Another factor reducing the tendency to opportunistic behaviour is the fact that the agent will not put his reputation at risk. This is because reputation is based on past activities of the entity which create repeatable, consistent pattern; it can be assumed that the reputation is a kind of promise as to how entities behave in the future. As long as this promise is fulfilled, reputation is enhanced, however, when the behaviour changes significantly and is not in line with the expectations arising from the previous pattern it may weaken the reputation. Entities with a good reputation will therefore be less likely to change their behaviour, owing to which they achieved reputation, because this change from their point of view could squander investments made in building reputation. This mechanism may work, for example, in the case of the too-big-to-fail and the too-important-to fail firms. Entities

15 S. Waddock, The Multiple Bottom Lines of Corporate Citizenship: Social Investing, Reputation and Responsibility Audits, „Business and Society Review”, Vol. 105, No. 3/2000, pp. 323-345.

${ }_{16}$ More about the benefits of a good reputation, see T.J. Dąbrowski, Reputacja przedsiębiorstwa. Tworzenie kapitatu zaufania, Wolters Kluwer, Kraków 2010, pp. 232-250.

17 J. Dobson, Corporate Reputation: A Free-Market Solution to Unethical Behavior, „Business and Society", Vol. 28, No. 1/1989, pp. 1-5. 
under these categories and at the same time which have a good reputation will be characterized by a lower propensity for excessive risk-taking, although their size and importance to the economy assure them protection from bankruptcy. State aid does allow such enterprises to survive; however, as evidenced by the results of the research, asking for aid involves the loss of reputation ${ }^{18}$. As a result, such entities attempt to avoid such choices which could possibly result in the need to use this type of aid.

Reputation not only creates incentives to reduce the tendency to opportunistic behaviour, but also allows entities, which could bear the negative effects of the bifurcated risk, to avoid getting involved in the relationships posing such threats. This property of reputation is related to its ability to equalize information asymmetry. This is because reputation, regardless of whether it is good or bad, carries with it the accumulated information on the characteristics of the organization and the manner of its conduct. The knowledge about permanent pattern of behaviour of the organization allows other entities to make choices about the manner of entering into a relationship with the organization. The role of reputation as an information medium can be seen, for example, in the company-customer relationship. Reputation reduces uncertainty on part of customers who can avoid those suppliers whose past behaviour indicates that buying their goods or services can have negative consequences.

Reputation as a mechanism to reduce the bifurcated risk has, however, some limitations because it implies that the effects of opportunistic behaviour are observable ex post for other parties to the contract. Otherwise, if the effects are not observable, these behaviours will not affect reputation, which means that it ceases to be an adequate mechanism to restrain this type of behaviour. The other mechanism to reduce the bifurcated risk - regulations, partially, do not have these limitations.

\section{REGULATIONS AS NON-MARKET MECHANISM TO REDUCE THE BIFURCATED RISK}

Individual cases of bifurcated risk (although not recognised as a spontaneous phenomenon), have been identified since long ago, usually when the neg-

18 The study noted the rapid deterioration of the financial institutions' reputation, which in the first phase of the crisis at the turn of 2008, received financial assistance from the State in the United States. A similar situation occurred in the case of the automotive industry. $C$ f. Harris Interactive, The 10th Annual RQ: Reputations of the 60 Most Visible Companies. A Survey of the U.S. General Public, December 2008-February 2009. 
ative consequences of this risk occurred. Temporary remedial measures were taken then and at the same time solutions were sought to prevent similar occurrences in the future. These solutions most often took the form of regulations, which in the form of legal standards or more discretionary recommendations provided by various kinds of regulatory bodies created in response to emerging problems, were supposed to be an antidote to opportunistic behaviour which poses a threat to other entities. In the case of the bifurcated risk the main objective of regulations is to reduce the possibility of transferring the effects of decisions on other entities, restore the relationship between decision-making and responsibility for its consequences (especially negative), increase transparency leading to a reduction in the level of information asymmetry.

Regulations, especially those taking the form of legal norms hedged around with state constraint, as a mechanism to reduce the bifurcated risk, have a number of weaknesses. First of all, they are quite expensive, because they require the existence of an efficient state apparatus responsible for monitoring and enforcing compliance with regulations. Besides, if they ensure too far-reaching protection of interests of one party they reduce this party's motivation to engage in actions to avoid the effects of risk taken by other entities. In addition, regulations based on restrictions and on formulating principles preferred by the legislature, (with an unchanged structure of incentives), often prove ineffective because when the incentives are strong enough the entities subject to regulations find their way to circumvent the rules (without breaking them, and usually continue the actions covered by the restrictions in a slightly modified form). It is also noted that the regulations are static while market conditions are characterized by high dynamics, therefore the solutions which perform well in one period, may bring unforeseen and undesirable consequences in the subsequent period.

Because the situations, in which abuse resulting from the bifurcated risk takes place, are very complicated, the law-making alone is not always enough. Sometimes regulatory and control bodies, acting on behalf of the state, must take ad hoc, discretionary decisions. The first such body, the Interstate Commerce Commission was established in the USA in 1887, and it was to restrict unfair competition in rail transport. In 2005, there were already 495 federal agencies in the US which means that annually four organizations of this type were established ${ }^{19}$. The example of the United States proves that

19 S. Sztaba, Ekonomiczna teoria regulacji w świetle doświadczeń polskiej transformacji gospodarczej, [in:] U. Zagóra-Jonszta (ed.), Dokonania wspótczesnej myśli ekonomicznej. Ekonomia instytucjonalna - teoria i praktyka, Wydawnictwo Akademii Ekonomicznej w Katowicach, Katowice 2006, p. 237. 
the development of regulatory bodies does not necessarily go hand in hand with a reduction of the bifurcated risk. Despite the large number and activity of regulators the US market is replete with examples of reported cases of risk taking, the effects of which were then transferred to other entities. These cases piled up and in fact were considered to be one of the sources of the financial crisis which started in the years 2007-2008. Thus, it seems that regulators do not perform well in preventing the bifurcated risk, but because they can immediately respond and their forms of action are flexible, they play an important role in supporting entities subject to the negative consequences of the bifurcated risk. It is important, because, in relation to the bifurcated risk, it is very difficult or even impossible to manage independently the exposure to the effects of this risk - either because of the significant or impossible-toremove information asymmetry, or because the subjects exposed to its effects are not able to free themselves from this risk.

Another form of institutionalization of protection against excessive generation of the bifurcated risk is self-regulation. It can be done at the level of the entire market, covering certain categories of entities (e.g., public companies), at the level of the industry, or at the level of individual companies. Self-regulation does not have certain weaknesses of the regulations with legal norms hedged around with state constraint, does not generate such high costs of enforcement of provisions contained therein, and does not result in a weakening of motivation of the other party to the contract to avoid the effects of risk taken by the entities covered by self-regulation. Experience has shown, however, that self-regulation requires external pressure, and often (though not always) reproduces merely solutions contained in legal norms.

\section{CONCLUSIONS}

The bifurcated risk is not a new phenomenon (although the term itself emerged relatively recently ${ }^{20}$ ) and deserves far more extensive research. Further research in this field appears to be necessary for two main reasons - firstly, with the increase in complexity of environment caused by technological changes the bifurcated risk will be spreading and its negative consequences will affect the ever increasing number of entities, and secondly, the escalation of this risk may cause harmful effects of the bifurcated risk on generalized

20 The term bifurcated risk, at that time translated as "fissional risk" in the abstract, was first used in A. Adamska, Ryzyko i odpowiedzialnośc, Zeszyty Naukowe Uniwersytetu Szczecińskiego No. 804 „Finanse, Rynki Finansowe, Ubezpieczenia”, No. 67/2014, pp. 177-184. 
trust. The erosion of generalized trust leads directly to an increase in transaction costs.

The growing importance of the bifurcated risk and its harmful effects should direct the research in this field to seek methods to reduce this risk. This article presents two types of mechanisms that can be used to reduce the risk - reputation as a market mechanism and regulations as a non-market mechanism. These mechanisms are complementary in nature - by interacting together they complement each other. At the same time due to their dissimilarity they provide entities responsible for shaping the institutional order with a choice - while trying to reduce the bifurcated risk either to put more emphasis on market mechanisms or focus on regulations.

\section{APPENDIX — METHODOLOGY}

The article deals with a new concept of "bifurcated risk" and two methods for its reduction - so it could be characterized in categories relevant to the nascent theory:

1. research questions about a phenomenon are open-ended;

2. methods for collecting data are observations;

3. collected data are qualitative, they are open-ended and need to be initially interpreted for meaning;

4. goal of data analyses is mainly pattern identification;

5. data analysis method is thematic content analysis for evidence of constructs;

6. theoretical contribution is a suggestive theory and invitation for further work on the issue ${ }^{21}$.

\section{BIBLIOGRAPHY}

Adamska A., Ryzyko i odpowiedzialność, Zeszyty Naukowe Uniwersytetu Szczecińskiego No. 804 „Finanse, Rynki Finansowe, Ubezpieczenia”, No. 67/2014.

Adamska A., Ryzyko jako przedmiot nauk ekonomicznych, [in:] K. Kuciński (ed.), Ryzyko lokalizacji przedsiębiorstw, CeDeWu, Warszawa 2014.

${ }^{21}$ See more at A.C. Edmondson, S.E. McManus, Methodological fit in management field research, „Academy of Management Review”, Vo. 32, No. 4/2007, p. 1155-1179. 
Adamska A., Ryzyko rozszczepione jako przejaw naruszonej rórwnowagi tadu instytucjonalnego w gospodarce, [in:] S. Rudolf (ed.), Teoretyczny i praktyczny wymiar nowej ekonomii instytucjonalnej, Kielce (in print).

Adamska A., Ryzyko w dziatalności przedsiębiorstwa - podstawowe zagadnienia, [in:] A. Fierla (ed.), Ryzyko w dziatalności przedsiębiorstw. Wybrane aspekty, Szkoła Główna Handlowa, Warszawa 2009.

Basdeo D.K., Smith K.G., Grimm C.M., Rindova V.P., Derfus P.J., The Impact of Market Actions on Firm Reputation, „Strategic Management Journal”, Vol. 27, No. 2/2006, http://dx.doi.org/10.1002/smj.556.

Dąbrowski T., Kryzys a teoria gier, czyli na czym polega btad, „Kwartalnik Nauk o Przedsiębiorstwie”, No. 1/ 2012.

Dąbrowski T.J., Reputacja przedsiębiorstwa. Tworzenie kapitatu zaufania, Wolters Kluwer, Kraków 2010.

Dobson J., Corporate Reputation: A Free-Market Solution to Unethical Behavior, „Business and Society”, Vol. 28, No. 1/1989, http://dx.doi. org/10.1177/000765038902800101.

Edmondson A.C., McManus S.E., Methodological fit in management field research, „Academy of Management Review", Vo. 32, No. 4/2007, http://dx.doi.org/10.5465/ amr.2007.26586086.

Fombrun C.J., Shanley M., What's in a name? Reputation building and corporate strategy, „Academy of Management Journal”, Vol. 33, No. 2/1990, http://dx.doi. org/10.2307/256324.

Harris Interactive, The $10^{\text {th }}$ Annual RQ: Reputations of the 60 Most Visible Companies. A Survey of the U.S. General Public, December 2008-February 2009.

Herbig P., Milewicz J., To be or not to be... credible that is: a model of reputation and credibility among competing firms, „Marketing Intelligence\&Planning”, Vol. 13, No. 6/1995, http://dx.doi.org/10.1108/02634509510094156.

Mesjasz C., Kontrakty niekompletne jako podstawa teoretyczna nadzoru korporacyjnego, [in:] S. Rudolf (ed.), Strategiczne obszary nadzoru korporacyjnego zewnętrznego i wewnętrznego, Wydawnictwo Uniwersytetu Łódzkiego, Łódź 2002.

Rappaport A., Wartość dla akcjonariuszy, WIG-Press, Warszawa 1999.

Spence A.M., Market Signaling: Informational Transfer in Hiring and Related Screening Processes, Harvard University Press, Cambridge 1974.

Sztaba S., Ekonomiczna teoria regulacji w świetle doświadczeń polskiej transformacji gospodarczej, [in:] U. Zagóra-Jonszta (ed.), Dokonania wspótczesnej myśli ekonomicznej. Ekonomia instytucjonalna - teoria i praktyka, Wydawnictwo Akademii Ekonomicznej w Katowicach, Katowice 2006.

Waddock S., The Multiple Bottom Lines of Corporate Citizenship: Social Investing, Reputation and Responsibility Audits, „Business and Society Review”, Vol. 105, No. 3/2000, http://dx.doi.org/10.1111/0045-3609.00085.

Wartick S.L., The relationship between intense media exposure and change in corporate reputation, „Business and Society”, Vol. 31, No. 1/1992, http://dx.doi. org/10.1177/000765039203100104. 
Weigelt K., Camerer C., Reputation and Corporate Strategy: a Review of Recent Theory and Applications, „Strategic Management Journal”, Vol. 9, No. 5/1988, http:// dx.doi.org/10.1002/smj.4250090505.

Wiśniewski P., Pokusa nadużycia implikowanej pomocy kredytowej. Jak ograniczý́ spoteczne koszty funkcjonowania przedsiębiorstw ważnych dla interesów panstwa?, „Studia i Prace Kolegium Zarządzania i Finansów”, Vol. 101/2010.

Yoon E., Guffey H.G., Kijewski V., The effects of information and company reputation on intentions to buy a business service, "Journal of Business Research”, Vol. 27, No. 3/1993, http://dx.doi.org/10.1016/0148-2963(93)90027-m. 